\title{
Linking great ape conservation and poverty alleviation Sharing experiences from Africa and Asia
}

\author{
Terry Sunderland', Dilys Roe², Tom Blomley³, Michael Day' and Linda Yuliani'
}

\section{Key points}

- Great apes occur in sub-Saharan Africa and southeast Asia. Efforts to link great ape conservation and poverty alleviation on the two continents share considerable similarities. The common issues allow the development of widely applicable guidelines and policy practice. However, the different sociopolitical, economic and ecological contexts of Africa and Asia need to be considered in developing any such guidance and practice.

- All six species of great ape are distributed in countries with high levels of rural poverty.

- The main threats to great apes in both Africa and Asia are large-scale land-use changes due to commercial enterprises such as oil palm plantations and logging, rather than local poverty. Nevertheless local poverty is a threat in fragmented forest habitats and in countries where the pressure on land is intense.

- The conservation of great apes has multiple links to poverty alleviation. Poverty can be a driver of local species loss. Conservation can either contribute to poverty alleviation or further exacerbate poverty, depending on how it is implemented and the benefits it generates. Many opportunities exist to link great ape conservation and poverty alleviation; however, inherent trade-offs must be considered. One of the most important is that all great apes are at serious risk of extinction, so conservation is the most critical priority. To that end national and international laws and conventions that protect great apes should be implemented and adhered to.

- The international interest in carbon conservation, and associated REDD $+{ }^{4}$ schemes, has the potential to provide significant co-benefits to great ape conservation and poverty alleviation by preserving forests of biodiversity value. However, REDD+ also presents risks to both local livelihoods and great apes due to a sole focus on carbon conservation. Potential risks include the exclusion of local people from forest resources and 'leakage' of forest degradation and deforestation activities from high-carbon forests to high-biodiversity forests, including those with great ape populations.

- Equitably managed great ape tourism can, in the right circumstances and in a limited number of sites, generate significant revenues and contribute to both great ape conservation and the livelihoods of local people.

- Conflict between humans and great apes can damage the livelihoods of poor people, for example by ape consumption of subsistence crops. Human-wildlife conflict can also undermine conservation efforts, such as through killing of great apes or loss of local support for conservation initiatives. Great ape tourism runs the risk of exacerbating such conflict because it is based on habituating great apes to humans.

\section{Background: the need to connect great ape conservation with poverty alleviation}

Great apes inhabit some of the poorest countries in the world, particularly in sub-Saharan Africa (Caldecott and Miles 2005). They attract a great deal of conservation interest due to their close genetic relationship with humans, their precarious survival status and their role as an icon for conservation. Consequently, they are often protected through strictly controlled and enforced conservation areas that can impair the livelihoods of poor local communities, such as through restrictions on resource access. At the same time, the economic benefits derived from great ape conservation, including great ape tourism where it is linked with conservation, are often not sufficiently shared with local people to generate real incentives for landscapescale conservation (Sandbrook and Roe 2010).
These two outcomes have implications of concern to both great ape conservation and development communities. Firstly, the valuable economic opportunities offered by great ape tourism may fail to realise their full potential to alleviate poverty. This also means that the value of conserving great apes, and biodiversity in general, is not factored into development policy and as a result their loss is not considered significant (TEEB 2010, Roe and Sunderland 2013).

Secondly, the actual, or perceived, negative impacts of conservation efforts may result in local antipathy, or even outright hostility, to them. While no systematic analysis has been made of the degree to which negative social impacts undermine conservation, many anecdotal examples can be found in the literature (e.g. Blomley et al. 2010). It has long been recognised that, as land and habitat become increasingly fragmented and human populations continue to grow, conservation 
can only be effective in the long term if it takes human needs into account. This was the foundation of the integrated conservation and development projects (ICDPs) that began in the 1980s and continue in various forms (McShane and Wells 2004).

Organisations concerned with biodiversity conservation are increasingly aware of the need to address human influences to achieve their conservation objectives. Often this is for purely pragmatic reasons (to reduce the threat to target species or habitats). However, for a number of organisations, including development agencies and those working for indigenous/local community rights, poverty alleviation is a key objective and biodiversity conservation is a mechanism to deliver on that objective. The Kinshasa Declaration on Great Apes ${ }^{5}$ - a high-level political statement on great ape conservation agreed in 2005 between governments, donor agencies and nongovernmental organisations (NGOs) - reinforced the connection between poverty alleviation and great ape conservation. However, for many organisations, achieving this connection is a particular challenge. Because they typically focus on biological conservation or poverty alleviation, they often lack either the development skills necessary to address social issues or the biological expertise necessary to address conservation issues.

Organisations are often ineffective at sharing information and experience on what works, and what doesn't, in linking conservation and poverty alleviation. As a result, much effort is duplicated, past failures are not learnt from, and opportunities to replicate or scale up successful approaches are missed.

\section{Exploring the link between great ape conservation and poverty alleviation}

Since 2004, the International Institute for Environment and Development (IIED) has coordinated an international network of conservation, development and indigenous/local community rights organisations, which is explicitly intended to address the knowledge, learning and support gap outlined above. The Poverty and Conservation Learning Group (PCLG) works by collecting, analysing and disseminating information that can help shape better policy and practise - through its web portal (www.povertyandconservation.info) workshops and symposia, and occasional publications. Since 2009, the PCLG has received additional support from the Arcus Foundation specifically to introduce a great ape conservation component to this work. From late-2009 to mid-2010, the group undertook a scoping study to explore the extent to which conservation and poverty projects are currently integrated in African great ape range states (Sandbrook and Roe 2010). This study reviewed, on a country-bycountry basis, which conservation organisations are operating and the extent to which they address poverty issues. It also identified development organisations working on biodiversity conservation. In 2010, the PCLG organised a workshop in Masindi, Uganda, to bring together organisations from different African great ape range states to share their experience on what works (and what doesn't) in terms of conserving great apes, engaging communities, generating income and reducing poverty. The workshop included participants from a variety of organisations and countries and identified a wide range of follow up activities at national, regional and international levels, from practical work on human-wildlife conflict to policy advocacy (PCLG 2010).

One of the outcomes of this workshop was an expressed desire to understand more about the comparative experience of linking great ape conservation and poverty alleviation in Asia. Consequently, in 2012, a meeting was hosted by the Center for International Forestry Research (CIFOR) in Bogor, Indonesia that brought together conservation practitioners and policymakers from Asia and Africa. They met to exchange experiences and to explore opportunities for applying those experiences from one continent to the other. The meeting focussed on opportunities associated with REDD+ schemes, great ape tourism and mitigating human-great ape conflict, and generated a number of policy recommendations, common to both African and Asian contexts, for linking great ape conservation with poverty alleviation. ${ }^{6}$

\section{African and Asian contexts and policy recommendations}

\section{REDD+}

REDD+ implementation is more advanced in Indonesia and Malaysia than in any of the African great ape range states. Many Asian countries also have greater political awareness and media coverage of REDD+ schemes and more technical and resource capacity among NGOs to develop such schemes. Nevertheless, some of the drivers of REDD+ are becoming increasingly important in Central Africa; for example, a number of Malaysian and Indonesian palm oil companies are scoping and purchasing land for oil palm development in countries such as Cameroon, the Democratic Republic of the Congo and Liberia. Asian experiences provide great potential for learning about mitigation of the negative impacts of palm oil production on great ape conservation.

In both continents, REDD+ has the potential to provide multiple benefits for great ape conservation and poverty alleviation, such as through the protection of great ape habitat, the replanting of forest areas for biodiversity, and the creation of employment opportunities. However, communities, researchers and government officials lack clarity as to what REDD+ is and what its implications are. In order for REDD+ to be effective and contribute to both great ape conservation and poverty alleviation, good governance and transparency are essential. REDD+ projects should also learn and build from previous attempts to combine conservation and poverty alleviation such as ICDPs, payments for environmental services schemes, and community-managed forests and protected areas.

\section{Policy recommendations - REDD+}

- Great ape range states should develop national and project safeguards and actions for REDD+ projects that promote attention to biodiversity including great apes.

- $\quad$ REDD+ schemes should contain national and project safeguards to ensure implementation does not adversely affect poor people.

- Clear communications are needed (using locally relevant language) to ensure local communities understand what REDD+ is and what its implications are. This should include managing local expectations as to REDD+ benefits, due to factors such as long timescales, long-term sustainability of funds, and the likelihood of long-term increases in local wildlife.

- $\quad$ REDD+ projects should be developed on a multistakeholder basis from their initiation, to enable the management of trade-offs, such as between national and district priorities.

- National policy and regulatory frameworks, land tenure and historical rights will have to be harmonised when dealing with REDD+ projects, including ones that straddle national boundaries.

- $\quad$ REDD+ funding will have to be managed transparently and address appropriate payment mechanisms to ensure fair and equitable benefit sharing.

6 These recommendations will be collated in detail as 'Best Practice Guidelines' for publication by the Primate Specialist Group of the International Union for Conservation of Nature (IUCN) 


\section{Linking ape conservation and poverty alleviation through REDD+, tourism and mitigating human-wildlife conflict: similarities and differences between Africa and Asia}

\begin{tabular}{|c|c|c|}
\hline Approach & Similarities & Differences \\
\hline REDD+ & $\begin{array}{l}\text { - Drivers of REDD+: land-use change, oil palm expansion/logging, presence } \\
\text { of large forest areas } \\
\text { - Potential for conservation benefits } \\
\text { - Lack of stakeholder understanding } \\
\text { - Uncertain timescales }\end{array}$ & $\begin{array}{l}\text { - REDD+ schemes more advanced in Asia } \\
\text { - More media coverage and political } \\
\text { awareness in Asia } \\
\text { - Greater capacity of NGOs/practitioners } \\
\text { for REDD+ planning in Asia }\end{array}$ \\
\hline Tourism & $\begin{array}{l}\text { - High demand for great ape tourism } \\
\text { - Potential for tourism to generate significant revenues } \\
\text { - Tourism needs to be properly managed in order to create livelihood and } \\
\text { conservation benefits } \\
\text { - Best practise guidelines exist } \\
\text { - Great ape habituation required for effective tourism } \\
\text { - Cases of uncoordinated land-use change and unregulated enterprise } \\
\text { development } \\
\text { - Increased risk of disease transmission and susceptibility to poaching of } \\
\text { great apes due to habituation } \\
\text { - Tourism potential to lead to greater security for protected areas due to } \\
\text { increased regulation of access }\end{array}$ & $\begin{array}{l}\text { - High-end exclusive tourism in Africa } \\
\text { versus cheap package tourism in Asia } \\
\text { - Greater regulation in Africa } \\
\text { - Viewing of semi-wild/rehabilitated } \\
\text { orangutans accounts for majority } \\
\text { of tourism in Asia compared to wild } \\
\text { chimpanzees and gorillas in Africa } \\
\text { - Fewer local benefits developed for } \\
\text { tourism in Asia }\end{array}$ \\
\hline $\begin{array}{l}\text { Human-wildlife } \\
\text { conflict }\end{array}$ & $\begin{array}{l}\text { - Impact of human-wildlife conflict has greatest impact on rural poor } \\
\text { people } \\
\text { - Large numbers of apes (mainly orangutans and chimpanzees) exist } \\
\text { outside of protected areas } \\
\text { - Compensation schemes inadequate } \\
\text { - Habituation of great apes for tourism can lead to increased human- } \\
\text { wildlife conflict } \\
\text { - Adverse impact on conservation objectives } \\
\text { - Scaring devices and guarding used to deter apes } \\
\text { - Translocation is costly, stressful for great apes and impractical } \\
\text { - Lack of knowledge among local communities regarding the protected } \\
\text { status of great apes }\end{array}$ & $\begin{array}{l}\text { - Orangutans mainly predate young oil } \\
\text { palms and not food crops } \\
\text { - Buffer zones of nonedible crops used in } \\
\text { African countries }\end{array}$ \\
\hline $\begin{array}{l}\text { General - ape } \\
\text { biology, status } \\
\text { etc. }\end{array}$ & $\begin{array}{l}\text { - All six species of great ape are classified as 'endangered' or 'critically } \\
\text { endangered' } \\
\text { - Large-scale land-use changes are among the main conservation threats } \\
\text { - Predominantly forest-dwelling species } \\
\text { - Great ape range states have high levels of rural poverty } \\
\text { - Slow rates of reproduction (particularly orangutans) }\end{array}$ & $\begin{array}{l}\text { - Great ape behaviour: predominantly } \\
\text { solitary orangutans compared to social } \\
\text { chimpanzees and gorillas } \\
\text { - Orangutans are found in only two Asian } \\
\text { countries (Malaysia and Indonesia) } \\
\text { compared to around } 20 \text { countries for } \\
\text { chimpanzees and } 10 \text { countries for gorillas }\end{array}$ \\
\hline
\end{tabular}

\section{Tourism}

In Africa, high revenues are generated from 'exclusive' great ape tourism, which is usually highly regulated (for example in Uganda gorilla permits alone are worth over US\$4 million a year). In many African great ape range countries local people are directly employed as trackers, guides and porters. They are also involved in great ape tourism through community enterprises, joint ventures and spin-off activities such as handicraft sales and cultural displays. By contrast, in Asia a focus on 'package tourism' has resulted in high numbers of tourists paying relatively low amounts of money to see orangutans (for example the foreign entrance fee to visit national parks with wild orangutans is well under $\$ 30$ per person/day). The more solitary and slow moving nature of orangutans, compared to group-living chimpanzees and gorillas, makes them harder to find and less interesting to view in the wild. As a result, great ape-based tourism in Asia does not presently, and may not have the potential, to generate the kinds of contributions to national economies that are seen in Africa, or the local revenues that can significantly alleviate poverty. Despite this, local people have developed small enterprises associated with tourism, including boat trips, which contributes to greater longterm conservation for orangutans and increased livelihood benefits for local people at some sites in Malaysia and Indonesia.
Tourism can also have numerous adverse effects on great ape conservation if not properly managed. Unregulated enterprise development, poor tourism management, and uncoordinated land-use planning has arisen in numerous great ape sites in both Africa and Asia. In Malaysia and Indonesia, the majority of great ape (orangutan) tourism is directed to former captive or semi-wild orangutans, which has been criticised for potentially diverting tourism income from in-situ conservation of wild orangutans. Habituation for the purpose of tourism makes great apes more susceptible to poaching, crop-raiding and other forms of conflict with humans. Disease transmission between humans and great apes is another serious problem in both continents. Tourists, especially foreign ones, potentially create serious disease risks for great apes.

\section{Policy recommendations - tourism}

- $\quad$ The potential for high-value great ape tourism should be explored in Indonesia and Malaysia.

- $\quad$ The IUCN best practice policy guidelines for great ape tourism (Macfie and Williamson 2010) should be adhered to in any new or existing tourism development.

- A national programme for conservation-oriented orangutan tourism will be required in order to implement high-end great ape tourism in Asia. This would include visitor regulations (e.g., visitor 
numbers, visit duration, behaviour, health, guide licensing), conservation management structures and authority, and a formal payment structure.

- Long-term finance must be secured before attempting to habituate great apes for tourism.

- When habituating great apes, individuals or groups located further from local communities should be chosen in order to reduce the potential for human-wildlife conflict.

- In order to enhance livelihood benefits, additional activities such as cultural tours should be promoted alongside ape tourism.

- Local capacity should be developed so that local people can gain the skills to benefit from working in great ape tourism.

\section{Human-great ape conflict}

Great apes can cause economic costs to poor people when raiding crops in particular. Human-great ape conflict can also adversely affect conservation objectives as humans kill problem-apes, capture great apes for the pet trade, transmit communicable diseases, as well as hunting them for the commercial bushmeat trade. Many great apes, including the majority of wild orangutans in Sumatra and Borneo, and chimpanzees in many African countries, live in unprotected habitat, where land-use change and increased population growth can easily increase the frequency of human-great ape conflict. In certain instances, successful conservation efforts may also increase the incidence of human-great ape conflict due to great ape population increases. Many countries provide compensation payments for livelihood damage caused by wildlife, great apes included, although conservationists are not convinced that this is appropriate and compensation can be insufficient.

\section{Policy recommendations - human-great ape conflict}

- The IUCN best practice guidelines on human-great ape conflict (Hockings and Humle 2009) should be adhered to in all cases.

- Translocation of problem-apes in conflict with humans should only be considered as a last resort.

- $\quad$ Recommendations need to be developed for handling livelihood damage caused by great apes that can reasonably be attributed to conservation efforts. Compensation has been provided in some areas but it raises serious problems from a conservation perspective, so alternatives need to be developed.

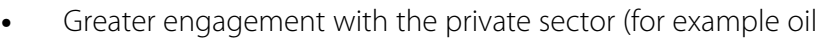
palm companies) is needed to effectively mitigate human-great ape conflicts; however, conservation authorities should maintain jurisdiction over the mitigation practices adopted, with the private sector covering the costs of the mitigation, including any follow-up.

\section{Acknowledgement}

The authors acknowledge the significant contribution of the participants of the workshop on "Great Apes and Poverty Linkages", held in Bogor in 11-13 January 2012. We thank the Indonesian Ministry of Forestry for support in the workshop organization and fieldtrip. Particular thanks are extended to Tatyana Humle, Liz Williamson, Liz McFie and Ann Russon for their detailed comments on earlier drafts of this InfoBrief. Further information on the workshop itself can be found at: http://www.cifor.org/ events/linking-great-ape-conservation-and-poverty-alleviation-live-videostream.html.

\section{References}

Blomley, T., Namara, A., McNeilage, A., Franks, P., Rainer, H., Donaldson, A. Malpas, R., Olupot, W., Baker, J., Sandbrook, C., et al. 2010 Development and gorillas? Assessing fifteen years of integrated conservation and development in south-western Uganda. Natural Resources Issues No. 23, International Institute for Environment and Development, London. http://pubs.iied.org/14592IIED.html.

Caldecott, J. and Miles, L. 2005 World atlas of great apes and their conservation. University of California Press, Berkeley and Los Angeles, California, USA.

Hockings, K. and Humle, T. 2009 Best practise guidelines for the prevention and mitigation of conflict between humans and great apes. IUCN/SSC Primate Specialist Group (PSG), Gland, Switzerland. http:// www.primate-sg.org/storage/pdf/BP.conflict.pdf.

Macfie, E.J. and Williamson, E.A. 2010 Best practise guidelines for great ape tourism. IUCN/SSC Primate Specialist Group (PSG), Gland, Switzerland. http://www.primate-sg.org/storage/PDF/BP.tourism.pdf

McShane, T.O. and Wells, M. (eds.) 2004 Getting biodiversity projects to work: Towards better conservation and development. Columbia University Press, New York, New York, USA

PCLG 2010 Linking great ape conservation and poverty alleviation: Learning from experiences and identifying new opportunities. Report of the Poverty and Conservation Learning Group workshop, Masinda, Uganda, October 2010. http://povertyandconservation.info/docs/ Masindi_Workshop_Report-Final.pdf.

Roe, D. and Sunderland T.C.H. 2013. Biodiversity conservation: An effective mechanism for poverty alleviation? In: Hari Bansha Dulal (ed.) Poverty reduction in a changing climate. Lexington Books, Lanham, Maryland, USA.

Sandbrook, C. and Roe, D. 2010 Linking conservation and poverty alleviation: The case of great apes. IIED Poverty and Conservation Learning Group Discussion Paper. International Institute for Environment and Development, London. http://pubs.iied.org/ G02770.html

TEEB 2010 Mainstreaming the economics of nature: A synthesis of the approach, conclusions and recommendations of TEEB. The Economics of Ecosystems and Biodiversity. http://www.teebweb.org/wp-content/ uploads/Study\%20and\%20Reports/Reports/Synthesis\%20report/ TEEB\%20Synthesis\%20Report\%202010.pdf.

This research was carried out by CIFOR as part of the CGIAR Research Program on Forests, Trees and Agroforestry. This collaborative program aims to enhance the management and use of forests, agroforestry and tree genetic resources across the landscape from forests to farms. CIFOR leads the program in partnership with Bioversity International, CIRAD (Centre de coopération internationale en recherche agronomique pour le développement), the International Center for Tropical Agriculture and the World Agroforestry Centre.

\section{arculs}

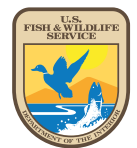

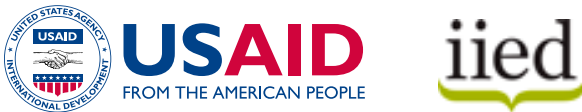

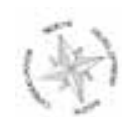

Poverty an

Conservation Learning Group

\section{cifor.org}

